University of the Pacific

Scholarly Commons

\title{
The International Law Commission Adopts Draft Articles on Transboundary Aquifers
}

Stephen C. McCaffrey

Pacific McGeorge School of Law

Follow this and additional works at: https://scholarlycommons.pacific.edu/facultyarticles

Part of the International Law Commons, and the Water Law Commons

\section{Recommended Citation}

Stephen C. McCaffrey, The International Law Commission Adopts Draft Articles on Transboundary Aquifers, 103 Am. J. Int'I L. 272 (2009).

This Article is brought to you for free and open access by the McGeorge School of Law Faculty Scholarship at Scholarly Commons. It has been accepted for inclusion in McGeorge School of Law Scholarly Articles by an authorized administrator of Scholarly Commons. For more information, please contact mgibney@pacific.edu. 


\title{
CURRENT DEVELOPMENTS
}

\section{THE INTERNATIONAL LAW COMMISSION ADOPTS DRAFT ARTICLES ON TRANSBOUNDARY AQUIFERS}

\author{
By Stephen C. McCaffrey
}




\title{
CURRENT DEVELOPMENTS
}

\section{THE INTERNATIONAL LAW COMMISSION ADOPTS DRAFT ARTICLES ON TRANSBOUNDARY AQUIFERS}

\author{
By Stephen C. McCaffrey*
}

At its 2008 session the United Nations International Law Commission (ILC) completed work on a set of nineteen draft articles on the law of transboundary aquifers and transmitted the draft to the General Assembly. ${ }^{1}$ The ILC recommended that the Assembly take note of the draft articles and at a later stage consider the elaboration of a convention based upon them. ${ }^{2}$

The Commission's work on transboundary groundwater was originally intended to complement its earlier draft articles on the law of the non-navigational uses of international watercourses, ${ }^{3}$ which formed the basis for the negotiation of the 1997 UN convention on the subject. ${ }^{4}$ Scientifically, the transboundary aquifers draft accurately and most usefully reflects the hydrology of aquifers, thanks to the assistance given the ILC by the United Nations Educational, Scientific and Cultural Organization (UNESCO) and other UN scientific bodies. Legally, however, the draft is less than a perfect fit with the UN Convention and introduces a novel, and potentially regressive, concept into the law in this field. After reviewing the background of the transboundary aquifers draft, this Note sets forth a general overview of its provisions and offers comments on the general approach of the draft and its relationship with the UN Convention.

\section{BACKGROUND}

When it adopted the final version of its draft articles on the law of the non-navigational uses of international watercourses in $1994,{ }^{5}$ the ILC also adopted a resolution on confined transboundary groundwater. ${ }^{6}$ The resolution reads in part as follows:

* University of the Pacific, McGeorge School of Law.

${ }^{1}$ Report of the International Law Commission on the Work of Its Sixtieth Session, UN GAOR, 62d Sess., Supp. No. 10, at 19, UN Doc. A/63/10 (2008) [hereinafter 2008 ILC Report]. The Commission's documents cited in this Note are available on the ILC Web site, <http://www.un.org/law/ilc/>, unless otherwise noted.

${ }^{2} 2008$ ILC Report, supra note 1, at 18.

${ }^{3}$ Report of the International Law Commission on the Work of Its Forty-sixth Session, [1994] 2 Y.B. Int'l L. Comm'n, pt. 2, at 89, UN Doc. A/49/10 (1994) [hereinafter 1994 ILC Report]; see Stephen C. McCaffrey, The International Law Commission Adopts Draft Articles on International Watercourses, 89 AJIL 395 (1995).

${ }^{4}$ Convention on the Law of the Non-navigational Uses of International Watercourses, May 21, 1997, 36 ILM 700 (1997) [hereinafter UN Convention].

51994 ILC Report, supra note 3, at 89.

${ }^{6}$ Resolution on Confined Transboundary Groundwater, id. at 135. 
The International Law Commission,

Having completed its consideration of the topic "The law of the non-navigational uses of international watercourses",

Having considered in that context groundwater which is related to an international watercourse,

Recognizing that confined groundwater, that is groundwater not related to an international watercourse, is also a natural resource of vital importance for sustaining life, health and the integrity of ecosystems,

Recognizing also the need for continuing efforts to elaborate rules pertaining to confined transboundary groundwater,

$\ldots$

1. Commends States to be guided by the principles contained in the draft articles on the law of the non-navigational uses of international watercourses, where appropriate, in regulating transboundary groundwater. ${ }^{7}$

The resolution thus recognized (in terms that were not altogether precise) that the draft articles on international watercourses cover "groundwater which is related to an international watercourse." ${ }^{8}$ This acknowledgment is important both legally and factually, since "[n]early all surface-water features (streams, lakes, reservoirs, wetlands, and estuaries) interact with ground water." While in this respect the resolution was redundant, as the draft articles (and the UN Convention) define "watercourse" to include both surface water and hydrologically related groundwater, ${ }^{10}$ the point was clear enough: the draft articles on international watercourses covered internationally shared surface water and related groundwater, but not groundwater that was unrelated to this "system"11 of surface and underground water-i.e., not "confined transboundary groundwater." ${ }^{12}$ Considering that an indication of its view as to the law governing this form of groundwater would be useful, the Commission, in the resolution's first operative paragraph, commended the principles in the international watercourses draft to states for guidance on the regulation of transboundary groundwater ${ }^{13}$ It could therefore be argued that no further action by the ILC was required on transboundary groundwater, since the Commission dealt with the part related to surface water in its international watercourses articles, and recommended that the principles contained in the latter articles be applied to confined transboundary aquifers. However, as seen, the ILC did recognize, in the resolution's preamble, "the need for continuing efforts to elaborate rules pertaining to confined transboundary groundwater." 14

${ }^{7} \mathrm{Id}$.

${ }^{8}$ Id., pmbl.

${ }^{9}$ Foreword to Thomas C. WINTER ET AL., Ground WATER AND SURFACE WATER: A Single ResourCE at III (U.S. Geological Survey Circular 1139, 1998), available at <http://pubs.usgs.gov/circ/circ1139/>.

${ }^{10}$ The draft articles, like the UN Convention, define "watercourse" to mean "a system of surface waters and groundwaters constituting by virtue of their physical relationship a unitary whole and normally flowing into a common terminus." Art. 2(b), 1994 ILC Report, supra note 3, at 90. "International watercourse" is defined simply as "a watercourse, parts of which are situated in different States." Art. 2(a), id.

${ }^{11}$ This term is used in the definition of "watercourse." See supra note 10.

12 See Commentary on Art. 2(b), 1994 ILC Report, supra note 3, at 90. The commentary notes: "Some members of the Commission ... believed that [confined] groundwater should be included within the term 'watercourse', provided that the aquifer in which it is contained is intersected by a boundary."

${ }^{13}$ Resolution on Confined Transboundary Groundwater, supra note 6, para. 1.

${ }^{14}$ Id., pmbl. 
In 2002 the ILC included the topic of shared natural resources in its program of work. The topic was understood to include groundwater, oil and natural gas, and perhaps other resources such as migratory birds and animals. ${ }^{15}$ The ILC appointed Chusei Yamada as special rapporteur for the topic. He "considered that it would be appropriate to begin with the consideration of groundwaters as the follow-up of the Commission's previous work on the codification of the law of surface waters." ${ }^{16}$ The reference to the previous work on surface waters is not altogether accurate since, as noted above, the ILC's previous work in the field dealt not only with surface water, but also with much of the world's groundwater: that which is hydrologically related to surface water. This point will be revisited below. The special rapporteur also stated that "the work on transboundary groundwaters could affect any future codification work by the Commission on oil and natural gas" and that "the Commission might also wish to take into account some relevant elements of the existing regulations and State practice on oil and natural gas before finalizing its work on transboundary groundwaters." ${ }^{17}$ (According to the ILC's commentary on the draft articles, "the overwhelming majority [of government comments on the $\mathrm{draft}$ supported the view that the law on transboundary aquifers should be treated independently of any future work of the Commission on the issues related to oil and natural gas." ${ }^{18}$ ) The special rapporteur thus posited a close relationship between the legal regimes governing transboundary groundwater, on the one hand, and oil and natural gas, on the other. He made no distinction between the commonly occurring groundwater that is hydrologically connected with surface water and groundwater, such as so-called fossil water, that is not so connected. As described in the following section, the ILC's transboundary aquifers draft addresses both forms.

\section{OVERVIEW OF THE DRAFT ARTICLES}

The ILC's draft on the law of transboundary aquifers consists of nineteen articles arranged in four parts: Introduction; General Principles; Protection, Preservation and Management; and Miscellaneous Provisions. ${ }^{19}$ The first of the two articles in part 1, Article 1, defines the scope of the draft as including "(a) Utilization of transboundary aquifers or aquifer systems; (b) Other activities that have or are likely to have an impact upon such aquifers or aquifer systems; and (c) Measures for the protection, preservation and management of such aquifers or aquifer systems." ${ }^{20}$ This broad definition takes into account, in paragraphs (b) and (c), that

\footnotetext{
${ }^{15}$ Report of the International Law Commission on the Work of Its Fifty-fourth Session, paras. 518-19, UN GAOR, 57th Sess., Supp. No. 10, at 243-44, UN Doc. A/57/10 (2002).

${ }^{16}$ Report of the International Law Commission on the Work of Its Fifty-eighth Session, UN GAOR, 61st Sess., Supp. No. 10, at 193, UN Doc. A/61/10 (2006) (referring to the UN Convention, supra note 4) [hereinafter 2006 ILC Report]. The Commission's previous work, of course, is that reflected in 1994 ILC Report, supra note 3.

${ }^{17} 2006$ ILC Report, supra note 16, at 193. The special rapporteur dealt with the relationship between the work on groundwaters and that on oil and gas in his fourth report, considered at the ILC's 2007 session. See Report of the International Law Commission on the Work of Its Fifty-ninth Session, UN GAOR, 62d Sess., Supp. No. 10, at 124, UN Doc. A/62/10 (2007) [hereinafter 2007 ILC Report]; see id. at 126 (summarizing the Commission's discussion of the fourth report].

${ }^{18}$ General commentary on the draft articles, para. 2, 2008 ILC Report, supra note 1, at 28.

19 These are the same titles as those used for parts I, II, IV, and VI, respectively, of the UN Convention, supra note 4 .

${ }^{20} 2008$ ILC Report, supra note 1, at 20.
} 
activities other than the use of groundwater per se-for example, disposal of waste on the surface of land in a recharge zone-may adversely affect shared groundwater. Article 2 contains all-important definitions of the terms used throughout the draft. These include (by relevant paragraph of Article 2) "aquifer" (a), "aquifer system" (b), "transboundary aquifer" or "transboundary aquifer system" (c), "aquifer State" (d), "utilization of transboundary aquifers or aquifer systems" (e), "recharging aquifer" (f), "recharge zone" (g), and "discharge zone" (h). ${ }^{21}$ (Note that there is no definition of "groundwater.")

The first of the seven articles of part 2, Article 3, Sovereignty of Aquifer States, proclaims the sovereignty of each aquifer state over the part of a transboundary aquifer or aquifer system located in its territory. ${ }^{22}$ This remarkable provision will be discussed further in the following section. It finds no counterpart in either the ILC's 1994 draft articles or the UN Convention.

Articles 4 through 8 correspond to Articles 5 through 9 of the UN Convention. In general, these articles are modeled upon the corresponding provisions of the UN Convention, with appropriate adaptations. Article 4, however, simply refers to "the principle of equitable and reasonable utilization" rather than adjusting the text of Article 5(1) of the Convention setting forth that principle. The draft article then proceeds to state how this principle applies to transboundary aquifers. ${ }^{23}$

Article 5 contains a nonexhaustive list of factors to be taken into account in ensuring that utilization of a transboundary aquifer is equitable and reasonable. The list generally tracks the one in Article 6 of the UN Convention (though the factors are reordered), again with appropriate modifications, but adds two factors: "(d) The contribution to the formation and recharge of the aquifer or aquifer system" and "(i) The role of the aquifer or aquifer system in the related ecosystem." According to the Commission's commentary, subparagraph (d) refers to "the comparative size of the aquifer in each aquifer State and the comparative importance of the recharge process in each State where the recharge zone is located." ${ }^{24}$ Subparagraph (d) thus goes beyond the UN Convention, which does not explicitly include the contribution of water by a given state as an indicative factor-although it may of course be relevant in a specific case and would thus be properly considered. Subparagraph (i) recognizes the importance of aquifers to sustaining the ecosystems related to them. The commentary describes the complex physical relationships characteristic of this function. ${ }^{25}$ Paragraph 2 of Article 5, concerning the weight to be given to the various factors, reproduces Article 6(2) of the UN Convention, with appropriate adjustments. But it also adds the concept of "vital human needs," which is contained in Article 10 of the Convention, Relationship Between Different Kinds of Uses (a provision that does not have a counterpart in the transboundary aquifers draft): "in weighing different kinds of utilization of a transboundary aquifer or aquifer system, special regard shall be given to vital

${ }^{21} I d$. at $20-21$.

${ }^{22} \mathrm{Id}$. at 21 .

${ }^{23}$ Interestingly, the Commission's commentary on Article 4 distinguishes between "equitable" and "reasonable" utilization of aquifers, explaining that three of the article's four paragraphs (relating to maximizing longterm benefits, para. (b); establishing comprehensive utilization plans, para. (c); and not overutilizing recharging transboundary aquifers, para. (d)) are "more related to reasonable utilization." Commentary on Art. 4, para. 4, id. at 42 .

${ }^{24}$ Commentary on Art. 5 , para. 4 , id. at 45.

${ }^{25}$ The commentary on paragraph (i) states that the expression "related ecosystem" should be understood in the context of the use of the term "ecosystem" in draft Article 10 on protection and preservation of ecosystems. Id. 
human needs." ${ }^{26}$ The intrinsic importance of this principle is magnified by its coming the closest in both instruments to recognizing the human right to water. ${ }^{27}$

Article 6, Obligation Not to Cause Significant Harm, is the counterpart of the article that caused the most difficulty in negotiating the UN Convention, Article 7. Yet the aquifers draft, rather than simply reproducing it with only the most necessary adaptations, adds a paragraph and rewords the Convention's critical paragraph 2 . The additional paragraph arguably is necessary; since it deals with "activities other than utilization of a transboundary aquifer . . . that have, or are likely to have, an impact upon that transboundary aquifer," ${ }^{28}$ it will help to prevent an unduly narrow reading of the obligation to prevent the causing of significant harm. Article 6 further reflects hydrologic reality in requiring that significant harm be prevented, not only with respect to other states sharing a transboundary aquifer, but also with respect to those "in whose territory a discharge zone is located." ${ }^{29}$ Whether this rewording of the rather awkwardly formulated Article 7(2) of the UN Convention will be judged an acceptable balancing of the no-harm and equitable utilization obligations remains to be seen. The Commission omitted even the weak reference to compensation in Article $7(2),{ }^{30}$ explaining that it is covered "by other rules of international law." 31

Article 7, on the general obligation to cooperate, generally follows Article 8 of the UN Convention but substitutes a terse provision for the somewhat long second paragraph on the establishment of joint management mechanisms that was added to Article 8 of the ILC's draft during the negotiation of the UN Convention. According to this paragraph of the aquifers draft, states sharing aquifers ("aquifer states" ${ }^{32}$ ) "should" establish such mechanisms. ${ }^{33}$

Article 8 , concerning the regular exchange of data and information, in large part tracks the corresponding provision of the UN Convention, Article 9. The Commission, however, added what is probably an essential paragraph calling upon states sharing aquifers to develop further data and information on those aquifers when necessary. ${ }^{34}$ Another change, which is less felicitous, moved the words "where appropriate" in the final paragraph of the article, so that it reads: "Aquifer States shall, where appropriate, employ their best efforts to collect and process data and information in a manner that facilitates their utilization by the other aquifer States to which such data and information are communicated." ${ }^{35}$ The UN Convention's version placed the words "where appropriate" before "process," giving them a more limited effect. Inserting them before all words of obligation in the paragraph considerably broadens their scope and

${ }^{26} \mathrm{Id}$. at 22. 2007).

${ }^{27}$ See generally STEPHEN C. MCCAFFrey, THE LAW OF INTERNATIONAL WATERCOURSES 369-71 (2d ed.

${ }^{28}$ Art. 6(2), 2008 ILC Report, supra note 1, at 22.

${ }^{29}$ Art. 6(3), id.

30 The states causing the harm are, "where appropriate, to discuss the question of compensation." UN Convention, supra note 4, Art. 7(2).

${ }^{31}$ Commentary on Art. 6, para. 5, 2008 ILC Report, supra note 1, at 47.

${ }^{32}$ Article 2(d) defines "aquifer State" to mean "a State in whose territory any part of a transboundary aquifer or aquifer system is situated." Id. at 20 .

33 "For the purpose of paragraph 1, aquifer States should establish joint mechanisms of cooperation." Art. 7(2), id. at 23.

${ }^{34}$ Art. 8(2), id.

${ }^{35}$ Art. 8(4), id. The UN Convention's counterpart provision reads: "Watercourse States shall employ their best efforts to collect and, where appropriate, to process data and information in a manner which facilitates its utilization by the other watercourse States to which it is communicated." UN Convention, supra note 4, Art. 9(3). 
weakens the article. Data and information collected by means of one system may not be usable by a state that employs another system. Yet the sharing of data and information is critical to the proper management of international watercourses, and to equitable utilization itself. Such sharing is particularly critical for groundwater, about which we have less knowledge than we do about surface water.

Article 9, Bilateral and Regional Agreements and Arrangements, at first appears to be a new provision. Closer examination, however, reveals that it largely reproduces, with appropriate modifications, the fourth paragraph of Article 3 of the UN Convention, Watercourse Agreements. The opening phrase of Article 9, however, gives rise to some confusion about the article's relationship with Articles 7 and 14 of the draft. That phrase states: "For the purpose of managing a particular transboundary aquifer or aquifer system ...."36 Article 7, it will be recalled, encourages states to "establish joint mechanisms of cooperation." The Commission's commentary makes clear that these mechanisms are envisioned as engaging in various forms of coordination and management. ${ }^{37}$ Article 14, Management, also deals with joint management mechanisms. Why the ILC decided to deal with joint management mechanisms in three different articles, rather than grouping the relevant provisions in a single article, remains uncertain. ${ }^{38}$ In addition, it might be asked whether a provision on bilateral and regional agreements and arrangements even belongs in a section of the draft on general principles.

Part 3 contains six articles, the first of which, Article 10, Protection and Preservation of Ecosystems, is based on Article 20 of the UN Convention. At first blush, it appears to weaken the latter provision somewhat by qualifying the obligation to protect transboundary aquiferrelated ecosystems with the words "take all appropriate measures." 39 These words generally connote an obligation of due diligence, or making best efforts under the circumstances. While the obligation to "protect and preserve the ecosystems of international watercourses" under Article 20 of the UN Convention is presumably one of due diligence even without these words, this interpretation is not entirely evident. ${ }^{40}$ The Commission's commentary indicates that the "obligation of States to take 'all appropriate measures' is limited to the protection of relevant ecosystems. This allows States greater flexibility in the implementation of their responsibilities under this provision." ${ }^{41}$ This explanation may raise more questions than it answers. Does it suggest that the words "take all appropriate measures" do not apply to the obligation to "preserve" aquifer-related ecosystems? This reading seems unlikely, yet that is what the commentary says on its face. Moreover, the explanation almost invites states to circumvent the basic obligation.

Article 11, concerning recharge and discharge zones, is new. These zones are areas of the land surface through which an aquifer is recharged, or replenished, or where water from an aquifer

${ }^{36}$ Art. 9, 2008 ILC Report, supra note 1, at 23.

${ }^{37}$ Commentary on Art. 7, id. at 49-50.

${ }^{38}$ One of the articles, Article 14, is located in a different part of the draft, part 3, from the other two, which are contained in part 2.

${ }^{39}$ Art. 10, 2008 ILC Report, supra note 1, at 24.

${ }^{40}$ While the "Statements of Understanding" adopted by the Working Group of the Whole of the Sixth Committee, in which the UN Convention was negotiated, state that Articles 21-23 of the Convention "impose a due diligence standard on watercourse States," they do not include Article 20 in this group. Report of the Sixth Committee Convening as the Working Group of the Whole at Its Second Session, para. 8, UN Doc. A/51/869, at 5 (Apr. 11, 1997), reprinted in 36 ILM 720 (1997).

${ }^{41}$ Commentary on Art. 10, para. 4, 2008 ILC Report, supra note 1, at 55. 
emerges from the ground into a watercourse of some kind (such as a stream or a lake) or into the sea. It is therefore crucial that they - recharge zones in particular-be protected to avoid the contamination of aquifers. Article 11 provides for the identification of such zones and for their protection from harmful impacts. Importantly, it further recognizes that either of these kinds of zones may be located in a state other than the one(s) where the aquifer is located, that is, the aquifer state(s). Article 11 requires such nonaquifer states to cooperate with aquifer states to protect the aquifer and related ecosystems. ${ }^{42}$ Yet whether nonaquifer states would be parties to any instrument based on the draft articles is uncertain.

Article 12, Prevention, Reduction and Control of Pollution, is based on paragraph 2 of Article 21 of the UN Convention. It is even more urgent to prevent the pollution of groundwater than that of surface water because once an aquifer is contaminated, it is ordinarily time-consuming and difficult, if not impossible, to restore its waters to their former unpolluted state. One would therefore have expected a detailed and robust provision on this subject. But in contrast to Article 21 of the Convention, which contains three rather lengthy and detailed paragraphs in this regard, Article 12 consists of a solitary paragraph of two sentences. Further, unlike Article 21 of the Convention, Article 12 surprisingly contains no definition of "pollution"; nor is that term defined anywhere else in the draft articles. One would think, for example, that it should be made clear that saltwater intrusion into an aquifer (such as by overabstraction of water from it) is a form of "pollution" for the purpose of this provision. Article 12 does require that states sharing transboundary aquifers "take a precautionary approach in view of uncertainty about the nature and extent of a transboundary aquifer or aquifer system and of its vulnerability to pollution." ${ }^{43}$ On the surface, this provision appears to be a positive, logical, and even necessary feature, precisely in view of the "vulnerability" of aquifers. But on reflection, the precautionary principle, or "approach," is addressed to situations in which there is scientific uncertainty about environmental harm. ${ }^{44}$ Little scientific uncertainty can be discerned about the harm pollution would cause to an aquifer. The Commission's commentary states that a precautionary approach is required in view of "the fragility and scientific uncertainty of aquifers." ${ }^{45}$ Aquifers are no doubt fragile, in the sense that care must be exercised with respect to their use and protection. There may also be "scientific uncertainty" about the precise nature, characteristics, and extent of a given aquifer. But, again, hardly anyone appears to doubt that aquifers are "vulnerab[le] to pollution," in the words of Article 12. It therefore seems more appropriate for Article 12 to have enjoined states to exercise a high degree of caution, perhaps even to take precautionary measures, so as to prevent pollution of shared aquifers, rather than to have invoked a principle or approach ${ }^{46}$ designed to deal with uncertainty.

${ }^{42}$ Art. 11(2), id. at 24 .

${ }^{43}$ Art. 12 , id.

${ }^{44}$ Perhaps the most broadly accepted general formulation of the precautionary "approach" is that of Principle 15 of the Rio Declaration on Environment and Development: "In order to protect the environment, the precautionary approach shall be widely applied by States according to their capabilities. Where there are threats of serious or irreversible damage, lack of full scientific certainty shall not be used as a reason for postponing cost-effective measures to prevent environmental degradation." Rio Declaration on Environment and Development, June 14, 1992, 31 ILM 874, 879 (1992).

${ }^{45}$ Commentary on Art. 12, para. 5, 2008 ILC Report, supra note 1, at 59.

${ }^{46}$ The ILC's commentary acknowledges the controversy as to whether it is a precautionary "approach" or "principle" and opts for the former on the ground that "it is the less disputed formulation." Id. 
Article 13 deals with monitoring, a critical subject in the case of groundwater. The article provides that states sharing aquifers are to monitor them jointly wherever possible, or at least to exchange data obtained through the monitoring process. ${ }^{47}$ States sharing aquifers "should" identify the parameters to be monitored, which should include "the condition of the aquifer or aquifer system . . . and also ... [their] utilization." 48

Article 14 requires "aquifer states" to "establish and implement plans for the proper management of their transboundary aquifers or aquifer systems." ${ }^{49}$ It does not state expressly whether this is to be done jointly or severally, but its second sentence suggests that the latter is intended: "[Aquifer states] shall, at the request of any of them, enter into consultations concerning the management of a transboundary aquifer . ..." ${ }^{\prime 0}$ Since transboundary groundwater is a shared resource, attempting to manage it unilaterally would be an exercise in futility, or worse: the consequences could easily amount to a tragedy of the commons. ${ }^{51}$ Management plans must therefore be prepared and implemented not only domestically, but also jointly, with other aquifer states. ${ }^{52}$ The article's final sentence provides that "[a] joint management mechanism shall be established, wherever appropriate." 53 As already noted, this is one of three places in the draft that management is dealt with (the others are Articles 7(2) and 9).

Article 15, Planned Activities, deals with the same subject as part 3 of the UN Convention, Planned Measures, which contains nine articles. (The ILC does not explain why it opted for the term "activities" rather than the broader expression "measures," as in the UN Convention.) In view of the sensitivity of aquifers, such extensive compression of the Commission's treatment of this important issue is somewhat surprising. The commentary explains that "a minimalist approach is taken in this draft article due to the scarcity of State practice with respect to aquifers." ${ }^{54}$ Since states look to the ILC for guidance, and since its mandate includes not only codification, but also progressive development of international law, this explanation is not entirely convincing-especially when one recalls that much of the world's groundwater is hydrologically connected with surface water. State practice in relation to surface water is therefore largely applicable to groundwater, as concluded by the International Law Association in

${ }^{47}$ Art. 13(1), id. at 24 .

${ }^{48}$ Art. $13(2)$, id. at $24-25$.

${ }^{49}$ Art. 14, id. at 25.

${ }^{50} \mathrm{Id}$.

${ }^{51}$ The reference here is to Garrett Hardin's well-known article, The Tragedy of the Commons, 162 SCIENCE 1243 (1968). Hardin uses the analogy of a pasture open to all herdsmen. The incentive of each is to increase his herd without limit, leading eventually to the destruction of the commons: "Ruin is the destination toward which all men rush, each pursuing his own best interest in a society that believes in the freedom of the commons. Freedom in a commons brings ruin to all." Id. at 1244. The same phenomenon would operate in the case of a shared aquifer.

${ }^{52}$ See in this connection the "Bellagio Draft Treaty," a model agreement for transboundary groundwater, in Robert D. Hayton \& Albert E. Utton, Transboundary Groundwaters: The Bellagio Draft Treaty, 29 NAT. RES. J. 663, 663 (1989) ("Withdrawals from one country can drain life-giving water from a neighboring country and, as a consequence, be the source of severe and protracted conflict. ... The draft provides mechanisms for the international aquifers in critical areas to be managed by mutual agreement rather than continuing to be subjected to unilateral taking."). Article VIII of the Bellagio Draft Treaty deals with comprehensive management plans, which are to be prepared by a joint commission, provided for in Article III and established by the states sharing the aquifer in question. Id. at 684, 695. Remarkably, the ILC's draft refers to the Bellagio Draft Treaty, a widely respected model for the management of shared groundwater, only for its definition of "aquifer." Commentary on Art. 2, 2008 ILC Report, supra note 1, at 34 n.23.

${ }^{53}$ Art. 14, 2008 ILC Report, supra note 1, at 25.

${ }^{54}$ Commentary on Art. 15, para. 1, id. at 66. 
its Seoul Rules on International Groundwaters. ${ }^{55}$ Article 15 begins with a paragraph that does not have a counterpart in the UN Convention but that would have been a welcome addition. It provides that, "as far as practicable," a state (whether or not it is an aquifer state ${ }^{56}$ ) is to assess the possible effects of an activity planned within its territory when it "has reasonable grounds for believing" that the activity may affect a transboundary aquifer in a way that could have "a significant adverse effect upon another State. " ${ }^{57}$ The two succeeding paragraphs of Article 15 are based upon Articles 12 and 17(1), respectively, of the UN Convention. They require prior notification of planned activities entailing potential adverse effects (paragraph 2) and consultations if the states concerned disagree about the possible effect of the planned measures (paragraph 3). ${ }^{58}$

Part 4 contains the final four articles of the draft. Article 16, a rather ambitious, though wellintentioned provision, purportedly requires all states ${ }^{59}$ (not merely aquifer states) to promote cooperation with developing countries with regard to the technical and legal aspects of the management and protection of transboundary aquifers. Like Article 15, this article thus seems to presume that any international agreement based on the draft articles would include not only states sharing transboundary aquifers but also others, and that at least some of those other states would be in a position to "promote" the kinds of "cooperation" envisaged in the article.

Article 17, Emergency Situations, tracks Article 28 of the UN Convention, ${ }^{60}$ and requires a state where an emergency originates to notify potentially affected states and competent international organizations and to take all practicable measures to prevent, mitigate, and eliminate any harmful effects of the emergency. ${ }^{61}$ In an innovation the article provides that a state "may take measures that are strictly necessary to meet" a threat to "vital human needs" posed by the emergency, "notwithstanding draft articles 4 and 6." ${ }^{2}$ Here the Commission evidently had in mind crises such as that occasioned by "the devastating tsunami disaster along the coast of the Indian Ocean," which "could flood seawater into an aquifer." ${ }^{63}$ Curiously, however, the commentary states that "[i]n the case of aquifers, emergencies might not be as numerous

\footnotetext{
55 The Seoul Rules on International Groundwaters adopted by the International Law Association (ILA) in 1986 make the ILA's 1966 Helsinki Rules applicable to groundwater. Rules on International Groundwaters, in 62 ILA, CONFERENCE REPORT 251 (1986) [hereinafter Seoul Rules on International Groundwaters]. The rules were adopted by the Resolution on International Water Resources Law, id. at 21.

${ }^{56}$ Commentary on Art. 15, para. 1, 2008 ILC Report, supra note 1, at 66.

${ }^{57}$ Art. $15(1)$, id. at 25.

${ }^{58}$ Paragraph 3 of Article 15 also states, in its final sentence, that the states concerned "may utilize an independent fact-finding body to make an impartial assessment of the effect of the planned activities." Art. 15(3), id. What this provision adds is unclear, since states are always free to have recourse to such third parties. The ILC refers in its commentary on this article to the compulsory fact-finding procedure set forth in Article 33 of the UN Convention, but states that "there exists no evidence as yet for such an obligation in relation to groundwaters." Commentary on Art. 15 , para. $6, i d$. at 68 . As indicated in the text at notes 54-55 supra, this explanation is not convincing.

${ }^{59}$ Article 16 begins: "States shall ... promote ... cooperation with developing States ...." Art. 16, chapeau, $i d$. at 25 . The commentary does not address what is intended by the initial reference to "States," but on the basis of other uses of the term, unmodified by the adjective "aquifer," in the draft, see, e.g., Art. 15, it seems reasonable to conclude that it refers to all states.

${ }^{60}$ See Commentary on Art. 17, para. 1, 2008 ILC Report, supra note 1, at 73 (stating that the UN Convention "contains a similar provision in article 28 ").

${ }^{61}$ Art. $17(2)$, id. at 26.

${ }^{62}$ Art. 17(3), id. Articles 4 and 6 set forth the obligations of equitable utilization and prevention of significant harm, respectively.

${ }^{63}$ Commentary on Art. 17, para. $1, i d$. at 73.
} 
and destructive as in the case of watercourses." ${ }^{34}$ Putting aside the continued confusion in terminology ${ }^{65}$ and unrealistic compartmentalization of surface water and groundwater, ${ }^{66} \mathrm{a}$ disaster affecting an aquifer could seemingly be far more destructive than one principally affecting surface water, since an aquifer would take considerably more time to cleanse itself than, for example, a surface stream.

Article 18, Protection in Time of Armed Conflict, is the counterpart to Article 29 of the UN Convention. The text of the two provisions is identical, save for the replacement of "international watercourses" with "transboundary aquifers or aquifer systems." ${ }^{67}$ Both state that the relevant freshwater resources enjoy the protection accorded by international law "in international and non-international armed conflict and shall not be used in violation of those principles and rules." 68

The final provision of the draft, Article 19, on data and information vital to national defense or security, is based on Article 31 of the UN Convention. Again, the substantive text of the two provisions is identical. In the case of Article 19, however, the expression "watercourse state" in the UN Convention is replaced with "state," purporting to make the article applicable to other states as well as to aquifer states. ${ }^{69}$ While the commentary offers no explanation for this expansion of coverage, the Commission presumably had in mind the same considerations as regards various other articles in the draft that also refer to a "state" or "states" without modification. ${ }^{70}$ Article 19 provides that states are not required to furnish data and information vital to their national defense or security but that they should provide "as much information as possible under the circumstances." 71

\section{EVALUATION}

In general, the transboundary aquifers draft seeks to apply the principles of the UN Convention, mutatis mutandis, to transboundary groundwater. Indeed, as has been seen, most of the substantive articles in the aquifers draft are based on the watercourses articles. ${ }^{72}$ Those that are not for the most part consist of refinements relating to the special characteristics of groundwater. ${ }^{73}$ This provenance validates the ILC's recommendation in its 1994 Resolution on Confined Transboundary Groundwater that in regulating transboundary groundwater, states

\footnotetext{
${ }^{64} \mathrm{Id}$.

${ }^{65}$ For the definition of "watercourse" in Article 2(a) of the UN Convention, see supra note 10.

${ }^{66}$ As indicated above, most surface water has associated groundwater. It does not accord with hydrologic reality to treat the two as entirely separate. See WINTER ET AL., supra note 9.

${ }^{67} 2008$ ILC Report, supra note 1, at 27.

${ }^{68} \mathrm{Id}$.

${ }^{69} \mathrm{Id}$.

${ }^{70}$ See Arts. 6, 11, 15, 16, 17.

${ }^{71} 2008$ ILC Report, supra note 1, at 27.

${ }^{72}$ The substantive provisions (i.e., those not involving scope and definitions) in the transboundary aquifers draft that do not have counterparts in the UN Convention are Article 3, Sovereignty of Aquifer States; Article 11, Recharge and Discharge Zones; Article 13, Monitoring; and Article 16, Technical Cooperation with Developing States.

${ }^{73}$ The statement that provisions of the aquifers draft that are not based on the UN Convention "for the most part" deal with the special characteristics of aquifers refers to the fact that Article 16, Technical Cooperation with Developing States, is more broadly applicable. Article 3, while inimical to the law of shared freshwater resources as discussed below, was apparently inspired by the characteristics of aquifers.
} 
should be guided, where appropriate, by the principles in the draft articles on non-navigational uses of international watercourses. ${ }^{74}$ But it also raises two broad questions: first, whether the aquifers draft has added anything new; and second, whether it has made a positive contribution to the development of the law of shared freshwater resources.

The first question must surely be answered in the affirmative, if only in a somewhat limited sense. The special rapporteur was able to arrange briefings for the Commission by groundwater experts from UNESCO, the Food and Agriculture Organization, the Economic Commission for Europe, and the International Association of Hydrogeologists. ${ }^{75}$ These briefings resulted in imparting a knowledge of aquifers, groundwater, and hydrogeology in general into the draft articles, giving them a scientifically sound basis. This achievement should not be underestimated since groundwater, while much more plentiful than surface water ${ }^{76}$ is far less understood by states and their political subdivisions. Injecting the language of hydrogeology into the discourse of international watercourse law is surely a good thing and has the potential to inform future agreements and arrangements between states concerning shared groundwater.

The second question, however, cannot be answered so unequivocally-perhaps in part because the Commission became so enamored of the science of aquifers that it lost sight of its main task: the codification and progressive development of the law of transboundary groundwater. In the context of the ILC's work, the difference between the terms "aquifers" and "groundwater," while it may seem subtle, is important. An aquifer is a geologic formation that contains water. The formation itself does not move; it is static. But the water-groundwater-it holds does move. It responds to a variety of forces, from gravity to withdrawals by the state in which it is located or a neighboring state. In short, it is not static. The special rapporteur had initially "indicated his intention to deal with confined transboundary groundwaters" before moving on to other shared natural resources. ${ }^{77}$ The decision to make the subject of the Commission's study, and thus its draft articles, the law of transboundary aquifers, rather than the law of transboundary groundwater (or, in the more restrictive terms of the ILC's 1994 resolution, the law of confined transboundary groundwater), may have been influenced by the briefings presented by the United Nations scientific agencies. In any event, the decision had major repercussions throughout the draft articles. These repercussions fall chiefly into two related categories: the physical and legal scope of the draft and its relationship with the UN Convention; and the decision to make the "sovereignty of aquifer states" the guiding principle of the draft. These points will be considered in turn.

\section{The Scope of the Draft and Its Relationship with the UN Convention}

First, the ILC's decision to make transboundary aquifers, rather than groundwater, the subject of the draft had far-reaching effects on its physical scope and thus on its relationship to the

\footnotetext{
${ }^{74}$ See note 6 supra and corresponding text.

752008 ILC Report, supra note 1, at 18.

${ }^{76}$ According to the United Nations Environment Programme, of all freshwater on Earth, only 0.3 percent is contained in lakes and rivers, while 30.8 percent is groundwater. The remaining 68.9 percent takes the form of glaciers and permanent snow cover. See Vital Water Graphics (2002), available at <http://www.unep.org/dewa/ assessments/ecosystems/water/vitalwater/01.htm $>$. In its commentary on the preamble to the draft, the ILC states that "[n]inety-seven per cent of readily available freshwater is stored underground." 2008 ILC Report, supra note 1 , at 31 , para. 2.

772008 ILC Report, supra note 1, at 13, para. 34.
} 
UN Convention. The draft defines "aquifer" as "a permeable water-bearing geological formation underlain by a less permeable layer and the water contained in the saturated zone of the formation. ${ }^{78}$ By focusing primarily on the geologic formation, and only secondarily referring to the "water contained in" it, the draft invites confusion as to whether the geological formation ( rock $^{79}$ ) or its content (water) is the primary subject of legal regulation. Unfortunately, the draft articles make clear that their overriding concern is with the rock, not the water. This emphasis is manifested all too plainly in the first general principle announced in the draft, "sovereignty of aquifer states," which seems to have become its leitmotif. The question whether a state enjoys anything but a limited form of sovereignty over shared groundwater bears upon the second category of repercussions, discussed below. Rather than focusing on the geologic formation, the draft articles could usefully have followed the approach of the International Law Association's 1986 Seoul Rules on International Groundwaters, which regulate "the waters of international aquifers." ${ }^{80}$

But even this definition of the draft's physical scope would be too broad if overlap with the UN Convention was to be avoided. The Convention, as indicated earlier, covers all groundwater that is hydrologically related to surface water. ${ }^{81}$ The only form of groundwater not covered by the 1997 UN Convention is that which does not interact with surface water, that is, water contained in what are sometimes referred to as "confined aquifers." 82 As understood by the Commission when it adopted its draft articles on international watercourses and the accompanying Resolution on Confined Transboundary Groundwater in 1994, confined aquifers do not receive significant recharge from surface water or otherwise (often because they are very deep) and do not discharge water to the surface or to other aquifers. Some regions of the world, principally the Middle East and North Africa, refer to this form of groundwater as "fossil water."

What the Commission envisaged in 1994 was that additional work could be done "to elaborate rules pertaining to confined transboundary groundwater," ${ }^{83}$ as this form of groundwater not only was not covered by the ILC's draft articles on international watercourses (or, consequently, the UN Convention) but also had not been considered by the Commission in its work on that project. Yet the scope of the transboundary aquifers draft is by no means limited to confined groundwater or aquifers. It purports to cover the water contained in all transboundary aquifers or aquifer systems, including those that are recharged from surface waters and discharge into those waters ${ }^{84}$ - precisely the forms of groundwater covered by the UN Convention. The two instruments therefore overlap with respect to all forms of groundwater except

${ }^{78}$ Art. 2(a), id. at 20.

79 The term "rock" is used for simplicity. As noted in the commentary, "[a] 'geological formation' consists of naturally occurring materials such as rock, gravel and sand." Commentary on Art. 2(a), para. 1, id. at 35.

${ }^{80}$ Seoul Rules on International Groundwaters, supra note 55, Art. 1, at 251 (entitled The Waters of International Aquifers) (emphasis added).

${ }^{81}$ See the UN Convention's definition of "watercourse," supra note 10.

${ }^{82}$ See, e.g., Commentary on Art. 2, para. 1, 2008 ILC Report, supra note 1, at 35: "All the aquifers are underlain by less permeable layers which serve, as it were, as the bottom of [a] container. Some aquifers are also upper-lain by less permeable layers. The waters stored in such aquifers are referred to as confined groundwaters as they are pressurized by more than atmospheric pressure."

${ }^{83}$ Resolution on Confined Transboundary Groundwater, supra note 6, pmbl.

${ }^{84}$ See the definitions of "recharging aquifer," "recharge zone," and "discharge zone" in Article 2(f), (g), and (h), 2008 ILC Report, supra note 1, at 20-21. 
confined transboundary groundwater, a point noted by some members of the Commission. ${ }^{85}$ This overlap is problematic for at least three reasons: first, it is likely to lead to confusion as to which instrument should apply to a situation that they both cover; second, the rules applicable to situations the two instruments cover are not perfectly congruent, as noted above; and third, and most fundamentally, the transboundary aquifers draft's use of "sovereignty" over transboundary aquifers as a guiding principle is entirely inconsistent with the UN Convention, as discussed below.

The problems created by overlap might at least have been ameliorated if the Commission had decided that the ultimate form of the transboundary aquifers draft would be a guide to practice that would assist states in their relations concerning transboundary groundwater. Precedent for such an approach can be found in the Commission's proposed outcome of its draft articles on reservations to treaties, ${ }^{86}$ and the General Assembly could still decide that the aquifers draft should be used in this way. But, evidently reflecting uncertainty as to how the transboundary aquifers draft would mesh with the UN Convention, ${ }^{87}$ the Commission, in its recommendation to the General Assembly on the final form of the draft, suggested neither this result nor the more usual form, a convention. Instead, the ILC proposed what it referred to as a "two-step approach," ${ }^{88}$ recommending to the General Assembly:

(a) To take note of the draft articles on the law of transboundary aquifers in a resolution, and to annex these articles to the resolution;

(b) To recommend to States concerned to make appropriate bilateral or regional arrangements for the proper management of their transboundary aquifers on the basis of the principles enunciated in these articles;

(c) To also consider, at a later stage, and in view of the importance of the topic, the elaboration of a convention on the basis of the draft articles. ${ }^{89}$

Presumably, the "two steps" are, first, recommendations (a) and (b), and, second, recommendation (c). Whether or not the last recommendation is taken up by the General Assembly, even "at a later stage," should depend in part on whether the aquifers draft can be made consistent with the law of international watercourses generally, as reflected in the UN Convention, and with the scope of the Convention.

It is worth noting in this connection that the ILC's Drafting Committee decided not to include the draft Article 20, Relation to Other Conventions and International Agreements, ${ }^{90}$ which had been proposed by the special rapporteur. That article reads as follows:

1. The present draft articles shall not alter the rights and obligations of the States parties which arise from other conventions and international agreements compatible with the

${ }^{85} \mathrm{Id}$. at 17 , para. 43 (describing consideration of special rapporteur's proposed Article 20, discussed in text at notes $90-92$ infra).

${ }^{86}$ See, e.g., id. at 136 , para. 68

${ }^{87} \mathrm{Id}$. at 15 , para. 39 (" $[\mathrm{I}]$ ssues concerning the relationship with other instruments were linked to questions concerning final form.").

${ }^{88} \mathrm{Id}$.

${ }^{89}$ Id. at 18, para. 49. In December 2008, the General Assembly decided to consider the form the draft articles might take during its sixty-sixth session in 2011. See note 138 infra.

${ }^{0}$ Why the Commission felt it necessary to refer to both "conventions" and "international agreements," since the latter is an all-embracing term for treaties, however named, is not known. See the definition of "treaty" in Article 2(a) of the Vienna Convention on the Law of Treaties, opened for signature May 23, 1969, 1155 UNTS 331. 
present draft articles and which do not affect the enjoyment by other States parties of their rights or the performance of their obligations under the present draft articles.

2. Notwithstanding the provisions of paragraph 1, when the States parties to the present draft articles are parties also to the Convention on the Law of the Non-navigational Uses of International Watercourses, the provisions of the latter concerning transboundary aquifers or aquifer systems apply only to the extent that they are compatible with those of the present draft articles. ${ }^{91}$

According to this draft article by the special rapporteur, the transboundary aquifers draft would prevail over any inconsistent instrument, including the UN Convention. This proposal stands in sharp contrast to the corresponding provision of the Convention itself, which provides that "[i]n the absence of an agreement to the contrary, nothing in the present Convention shall affect the rights or obligations of a watercourse State arising from agreements in force for it on the date on which it became a party to the present Convention." ${ }^{22}$ In light of the sweeping effect of the special rapporteur's proposed Article 20, its deletion by the Drafting Committee is perhaps not surprising.

A final point relating to the physical scope of the draft is that if it is to overlap with the UN Convention, it seems unnecessarily and unhelpfully limited in one respect. An aquifer may be situated entirely in one state but contribute water to a surface stream that flows from that state into another state. Such an aquifer is not covered by the terms "transboundary aquifer" and "transboundary aquifer system," as defined in the draft; at most, it would be covered by the article on "recharge and discharge zones," ${ }^{3}$ but the general principles contained in the draft evidently do not apply to those zones, as they govern transboundary aquifers and aquifer systems. Since the principles contained in the draft should logically apply to the waters of aquifers or aquifer systems that are located in a single state but contribute to the surface waters of an international watercourse, such aquifers should be covered by the draft; why they are not remains unclear. Such aquifers are covered by the 1997 UN Convention, but since other forms of groundwater covered by the Convention are also covered by the draft, it would not seem that avoiding overlap with the Convention is the reason that the current draft excludes this particular form of groundwater.

\section{Sovereignty of Aquifer States}

The second category of repercussions of the ILC's decision to study transboundary aquifers rather than transboundary groundwater relates to the consequent centering of the draft on the concept of "sovereignty of aquifer states." ${ }^{44}$ Article 3 of the ILC's aquifers draft provides as follows: "Each aquifer State has sovereignty over the portion of a transboundary aquifer or aquifer system located within its territory. It shall exercise its sovereignty in accordance with international law and the present draft articles." 95

${ }^{91} 2008$ ILC Report, supra note 1 , at 15 n.13.

${ }^{92}$ UN Convention, supra note 4, Art. 3(1).

${ }^{93}$ Article 10, Recharge and Discharge Zones, 2008 ILC Report, supra note 1, at 24.

${ }^{44}$ See generally Margaret J. Vick, International Water Law and Sovereignty: A Discussion of the ILC Draft Articles on the Law of Transboundary Aquifers, 21 PAC. MCGEORGE GLOBAL BUS. \& DEV. L.J. 191 (2008).

952008 ILC Report, supra note 1, at 21. 
The ILC's commentary on Article 3 cites a number of treaties and nonbinding instruments purportedly supporting this provision. ${ }^{96}$ Only two of those instruments concern freshwater; none relates specifically to aquifers or groundwater and none refers to sovereignty over shared freshwater of any kind. ${ }^{97}$ The only way that either of the two freshwater agreements refers to sovereignty is by reproducing the general formula of Principle 2 of the Rio Declaration on Environment and Development, which refers to states' "sovereign right to exploit their own resources" " "in accordance with the Charter of the United Nations and the principles of international law") in the context of emphasizing their "responsibility to ensure that activities within their jurisdiction or control do not cause damage to the environment of other states." 98 Unfortunately, Article 3 does not take Principle 2's additional and important second step of underscoring the responsibility of states to ensure that activities within their jurisdiction that affect transboundary groundwater do not cause damage to other states. This may be one reason some states suggested adding to the second sentence of Article 3 the words "international law and" to the version of the article adopted on first reading. ${ }^{99}$ That version had only required that a state's "sovereignty over . . . a transboundary aquifer" be exercised "in accordance with the present draft articles."

If the subject matter being regulated is an immovable part of the territory of states, it is only natural to conceive of states as having "sovereignty" over it. But if the subject matter is something that moves from one state to another, from underground to surface, from surface to atmosphere, from atmosphere back to surface, and so on in the hydrologic cycle, the notion that states have sovereignty over it seems a far from perfect match. Considering the language of Article 3 and the commentary on the draft, the Commission seems to have had the first kind of subject matter in mind: both refer to a part of an aquifer "located" within a state's territory. According to the commentary, "In essence, each aquifer State has sovereignty over the transboundary aquifer or aquifer system to the extent located within its territory." ${ }^{100}$ An aquiferrock - can be "located" within a state. The term "located," which is used in the sense of "situated," 101 does not accurately describe something moving, such as water flowing through an aquifer. A substance moving from one state to another is not something that accords with

${ }^{96}$ Commentary on Art. 3, id. at 39 n. 24 .

${ }^{97}$ This is not the place for an analysis of each of the treaties and nonbinding instruments referred to in note 24 of the ILC's commentary. Suffice it to say that they relate to a wide variety of subject matters, from the ozone layer and biodiversity to succession of states and the law of the sea. Only two of the instruments actually concern freshwater, and one of those, the 2003 Convention on the Sustainable Development of Lake Tanganyika, reproduces Principle 2 of the Rio Declaration on Environment and Development, supra note 44, in its preamble. Many of the other instruments cited reproduce Principle 2 as well. In providing that "States have. . . the sovereign right to exploit their own resources," 31 ILM at 876 (emphasis added), Principle 2 is not saying the same thing as that states have "sovereignty over" those resources; nor is there any reference to shared natural resources. The other instrument relating to freshwater, the 1999 Protocol on Water and Health to the 1992 ECE Convention on the Protection and Use of Transboundary Watercourses and International Lakes, also reproduces Principle 2 of the Rio Declaration in its Article 5(c). Not one instrument cited is devoted to transboundary groundwater.

${ }^{98}$ Rio Declaration on Environment and Development, supra note 44, princ. 2, 31 ILM at 876.

${ }^{99}$ See the comments of Brazil and Israel, in Shared Natural Resources, Comments and Observations by Governments on the Draft Articles on the Law of Transboundary Aquifers, at 22, UN Doc. A/CN.4/595 (Mar. 26, 2008) [hereinafter Comments and Observations by Governments], available at <http://documents.un.org/ default.asp $>$.

${ }^{100}$ Commentary on Art. 3, para. 3, 2008 ILC Report, supra note 1, at 40.

101 "[H] aving a site, situation, or location: LOCATED." MERRIAM-WEBSTER'S COLLEGIATE DICTIONARY 1166 (11th ed. 2003). 
normal conceptions of what falls under a state's sovereignty: its territory, including its territorial sea. ${ }^{102}$

Justice Oliver Wendell Holmes, speaking of a treaty with Canada concerning migratory birds, captured the idea well in a case involving the U.S. state of Missouri's claim of exclusive authority over the birds. ${ }^{103}$ Justice Holmes observed that such a claim rested on "the presence within their jurisdiction of birds that yesterday had not arrived, tomorrow may be in another State and in a week a thousand miles away." ${ }^{104} \mathrm{He}$ declared: "Here a national interest of very nearly the first magnitude is involved. It can be protected only by national action in concert with that of another power. ... But for the treaty and the [implementing] statute there soon might be no birds for any powers to deal with." 105 Similarly, without cooperation with other states sharing transboundary groundwater, an approach afforded little incentive by the idea of sovereignty, "there soon might be no [groundwater] for any powers to deal with." With regard to water in particular, the first Restatement of Torts captures the idea eloquently:

Water, like air and light, is a fugitive, wandering thing, flowing over and through land, but seldom remaining for any length of time in one place or within the confines of any one person's possession. One's dominion over it while it is upon his land is temporary, and since it ordinarily flows onto the lands of other persons, it is a thing common to the lands of all through whose possession it passes. Unlike air, it is limited in quantity, and a substantial use of it by one may prevent others from having it. ... [T] he rights and privileges of individual users are subject to greater limitation out of regard for the common interests of all. ${ }^{106}$

In short, the rights of a state in the groundwater contained in the portion of a transboundary aquifer within its territory are unlike those the state enjoys over its land territory. Shared groundwater may move slowly, but it does move; it is more akin in this respect to the migratory bird or the flowing stream than the geologic formation constituting an aquifer. For that reason, states have long recognized that their rights in shared freshwater resources are not appropriately described with reference to the concept of sovereignty. ${ }^{107}$ Instead, they have accepted that they each have rights in the shared resource and obligations with respect to it, and that the determination of their respective shares of the resource is governed by the principle of equitable and reasonable utilization. ${ }^{108}$

The UN Convention and all drafts on the law of international watercourses prepared by scholarly and professional organizations ${ }^{109}$ reject as both unhelpful and unsupported by state

\footnotetext{
102 The ILC's commentary implies, without being entirely clear, that this is the meaning of sovereignty it had in mind in the draft articles: "The term 'sovereignty' here is a reference to sovereignty over an aquifer located within the territory of an aquifer State, including the territorial sea ..." Commentary on Art. 3, para. 4, 2008 ILC Report, supra note 1 , at 40 .

${ }^{103}$ Missouri v. Holland, 252 U.S. 416 (1920).

${ }^{104} I d$. at 434 .

${ }^{105} I d$. at 435 .

${ }^{106}$ RESTATEMENT OF TORTS, ch. 41, topic 3, Analysis, at 350 (1939).

107 See, e.g., MCCAFFREY, supra note 27, at 111-70.

${ }^{108}$ See Commentary on draft Art. 5, Equitable and Reasonable Utilization and Participation, 1994 ILC Report, supra note 3, at 96; see also MCCAFFREY, supra note 27, at 384-405.

109 See Helsinki Rules on the Uses of the Waters of International Rivers, 52 ILA, CONFERENCE REPORT 484 (1966); Seoul Rules on International Groundwaters, supra note 55; see also Resolution on the Use of International Non-Maritime Waters, Sept. 11, 1961, [1961] 2 ANNUAIRE DE L'INSTITUT DE DROIT INTERNATIONAL 381;
} 
practice the notion that a state "has sovereignty over the portion of" shared freshwater resources located within its territory. According to these authorities, and the ILC's own work on international watercourses, ${ }^{110}$ the doctrine of sovereignty does not apply to shared freshwater resources in any way that resembles its application to land territory. The confusion regarding the applicability of sovereignty to shared groundwater may have been engendered by the definition of the term "aquifer," as discussed above, and also by the special rapporteur's having linked the legal regimes governing transboundary aquifers and shared hydrocarbons. ${ }^{11}$ The special rapporteur thus posited a close relationship between the legal regimes governing transboundary groundwater, on the one hand, and shared hydrocarbon resources, on the other, a novel notion ${ }^{112}$ whose validity is highly doubtful in view of the entirely separate development of the two regimes.

In the Gabčikovo-Nagymaros Project case, which involved both surface water and groundwater, ${ }^{113}$ neither Hungary nor Slovakia relied on a doctrine of sovereignty over the portion of the shared resource located in its territory. In its judgment, the International Court of Justice (ICJ) left no doubt that such a notion does not apply to international watercourses:

In 1929, the Permanent Court of International Justice, with regard to navigation on the River Oder, stated as follows:

"[the] community of interest in a navigable river becomes the basis of a common legal right, the essential features of which are the perfect equality of all riparian States in the use[ ] of the whole course of the river and the exclusion of any preferential privilege of any one riparian State in relation to the others".

Modern development of international law has strengthened this principle for nonnavigational uses of international watercourses as well, as evidenced by the adoption of the Convention of 21 May 1997 on the Law of the Non-Navigational Uses of International Watercourses by the United Nations General Assembly. ${ }^{114}$

The ICJ therefore confirmed that the principle of community of interest applies to nonnavigational uses of international watercourses. As has been seen, the UN Convention defines the term "watercourse" to include both surface water and groundwater that interacts with it, and the Court was surely aware of that definition. ${ }^{15}$ The notion of "sovereignty" over the portion of shared freshwater resources situated in a state's territory is incompatible with the principle of community of interest in those resources. The concept of "sovereignty" over shared

\footnotetext{
"Berlin Rules on International Water Resources," 71 ILA, CONFERENCE REPORT 336, 343 (2004) (revising and updating the Helsinki Rules), available at <http://www.asil.org/ilib/WaterReport2004.pdf>.

${ }^{110}$ See 1994 ILC Report, supra note 3, at 89.

111 See note 17 supra and corresponding text.

${ }^{112}$ The ILC's previous work on shared freshwater resources did not rely at all on the legal regimes governing shared oil and natural gas. See the draft articles and commentaries on the law of international watercourses adopted by the Commission in 1994, 1994 ILC Report, supra note 3, at 89. The same is true of the work of the Institut de droit international and the International Law Association, supra note 109.

113 The surface water was, of course, the Danube River, on a long stretch of which the project was located. The groundwater was that associated with the surface water, primarily in the vicinity of the Gabčíkovo barrage, but also in wells farther downstream near the banks of the river ("bank-filtered wells"). See, e.g., Gabčíkovo-Nagymaros Project (Hung./Slovk.), 1997 ICJ REP. 7, 35-36, para. 40; 43, para. 56; \& 74, para. 127 (Sept. 25).

${ }^{114}$ Id. at 56, para. 85 (quoting Territorial Jurisdiction of the International Commission of the River Oder, 1929 PCIJ (ser. A) No. 23, at 27 (citation omitted)).

${ }^{115}$ Beyond the close relationship between the ILC and the ICJ, the Court's president at the time, Stephen M. Schwebel, was a former special rapporteur for the ILC on international watercourses, and the Court's membership included other former members of the Commission.
} 
groundwater cannot possibly be squared with "the exclusion of any preferential privilege of any one riparian State in relation to the others." In the Oder case, the Permanent Court ruled against Poland's contention that the international regime of two tributaries of the Oder should extend only up to the Polish border-effectively, an argument that Polish sovereignty over those rivers once they crossed the Polish border made them noninternational. The Court based its decision largely on the "community of interest" principle, which the ICJ applied to non-navigational uses in the passage quoted above. The ICJ may thus be said to have rejected the notion that a state has "sovereignty" over the portion of an international watercourse (including groundwater) that is situated in its territory. Rather, other states sharing that resource have an "interest" in it together with the territorial state. The states sharing the interest form a "community" whose existence is based on the fact that they share the resource.

Unfortunately, in its commentary on Article 3 the Commission does not clarify what it intended to imply by a state's "sovereignty" over the portion of a transboundary aquifer located in its territory. The first sentence of that commentary states as follows:

The need to have an explicit reference in the form of [a] draft article to the sovereignty of States over the natural resources within their territories was reaffirmed by many States, particularly by those aquifer States that are of the opinion that water resources belong to the States in which they are located and are subject to the exclusive sovereignty of those States. ${ }^{116}$

This characterization of the views of some states supporting Article 3, specifically the clause beginning with "particularly," is breathtaking in both its comprehensiveness and its absoluteness: the expression "water resources" is not qualified, meaning that it would include all forms of shared freshwater resources, not only transboundary groundwater; and these states are said to take the view that water resources "belong" to the states where they are located and "are subject to the exclusive sovereignty of those States." This statement strongly echoes the infamous "Harmon Doctrine" of absolute sovereignty over international watercourses, ${ }^{117}$ which has long since been discredited, not least by the state of its origin, the United States. ${ }^{118}$

Nevertheless, one may question whether "many" states actually expressed the view that an article on sovereignty over transboundary aquifers was needed. One measure of the strength of a state's commitment to a provision of an ILC draft is whether it submits written comments on the provision as adopted on first reading in response to the Commission's request. ${ }^{119}$ By this standard there does not seem to have been a great deal of interest in Article 3, or indeed in the

\footnotetext{
${ }^{116}$ Commentary on Art. 3, para. 1, 2008 ILC Report, supra note 1, at 38-39.

117 The "Harmon Doctrine" of absolute sovereignty was articulated by Attorney General Judson Harmon of the United States in 1895 in a dispute with Mexico over the Rio Grande. 21 Op. Att'y Gen. 274 (1895), available in 1895 U.S. AG LEXIS 4. The dispute was resolved in the Convention Providing for the Equitable Distribution of the Waters of the Rio Grande for Irrigation Purposes, U.S.-Mex., May 21, 1906, 34 Stat. 2953. See generally MCCAFFREY, supra note 27, at 76-110.

${ }^{118}$ The United States disavowed the Harmon Doctrine in the context of a later dispute with Canada, stating that it never represented international law. See, e.g., WILLIAM L. GRIFFIN, LEGAL ASPECTS OF THE USE OF SYSTEMS OF INTERNATIONAL WATERS, S. DOC. NO. 85-118, at 59-63 (1958) (reprinting Memorandum of the U.S. Dep't of State, Apr. 21, 1958).

${ }^{119}$ See 2006 ILC Report, supra note 16, at 184, para. 73. This practice is followed by the ILC for all of its drafts, as provided for in Articles 16-21 of its Statute. ILC Statute, as amended, Arts. 16-21, UN Doc. A/CN.4/4/Rev.2 (1982). Governments are typically given a year to submit their written comments and observations. The ILC then
} 
aquifers draft as a whole, when the ILC adopted the draft articles on first reading in 2006: only a small number of states explicitly supported the notion of sovereignty over transboundary aquifers and no governments stated that they supported the proposition that "water resources belong to the States in which they are located and are subject to the exclusive sovereignty of those States." 120 Specifically, the Commission reports that only eighteen states submitted comments on the draft articles as adopted on first reading and, of those, only six (Austria, Brazil, Cuba, Israel, Portugal, and Turkey) commented on draft Article $3 .{ }^{121}$ Of those six states, three (Austria, Brazil, and Turkey) are upstream or predominantly upstream, one (Israel) is upstream on one of the four aquifers it shares with the Palestinians, one (Portugal) is predominantly downstream, and one (Cuba) has no international watercourses. (Historically, to the extent that sovereignty over shared freshwater resources has been asserted, upstream states have generally been the ones to have done so.) Of these states, only Portugal commented that cooperation should be emphasized and that the ILC should "reflect upon whether or not to shift towards a more actual and mitigated doctrine of sovereignty." ${ }^{122}$ The remaining five offered varying degrees of support for Article 3, although two of these insisted that the article be amended to provide that a state's sovereignty over transboundary aquifers should be exercised in accordance with international law. ${ }^{123}$ One of these states explained that it "does not support the making of exceptions to accepted customary international law on this issue." ${ }^{124}$ All told, among the states with international watercourses (including transboundary aquifers) that commented, four would not seem to qualify as "many." Additional governments may have made specific oral comments on Article 3 during the annual discussion of the Commission's reports in the Sixth (Legal) Committee of the General Assembly. However, the topical summaries of those debates in 2006 and $2007^{125}$ indicate that only "some" delegations addressed Article 3 , and that they made substantially the same points as were made in the written comments and referred to in the Commission's commentary. ${ }^{126}$

Even if the number of states arguing the "need" for a provision on sovereignty over the portion of shared natural resources within their territories had been greater, that alone should not have been enough to persuade the Commission to include such a provision in its draft in the face of contrary state practice. Traditionally, in carrying out its task of the "progressive development of international law and its codification," 127 the ILC has taken into account all the

gives the draft articles a second reading taking into consideration the comments that have been submitted. Also available to the ILC are topical summaries, prepared by the UN Secretariat, of the debates held in the Sixth (Legal) Committee of the General Assembly on the ILC's annual reports.

${ }^{120}$ See text at note 116 supra.

${ }^{121}$ Comments and Observations by Governments, supra note 99, at 21-22. In fairness, only twenty-one states submitted comments on the international watercourses articles adopted on first reading. See UN Doc. A/CN.4/447 \& Adds. 1, 2, 3 (1993). Unfortunately, low response rates to ILC requests for government comments on its drafts are not unusual. But states with strong interests in a given draft can be expected to submit comments.

${ }^{122}$ Comments and Observations by Governments, supra note 99, at 22.

${ }^{123} I d$. (Brazil and Israel). These countries seem to have feared making the draft articles the sole limitation on a state's exercise of sovereignty.

${ }^{124} I d$., comment of Israel.

125 Topical Summary of the Discussion Held in the Sixth Committee of the General Assembly During Its Sixtyfirst Session, Prepared by the Secretariat, UN Doc. A/CN.4/577 (Jan. 19, 2007); Topical Summary of the Discussion Held in the Sixth Committee of the General Assembly During Its Sixty-second Session, Prepared by the Secretariat, UN Doc. A/CN.4/588 (Jan. 24, 2008), available at <http://documents.un.org/default.asp>.

${ }^{126} 2008$ ILC Report, supra note 1, at 38-39.

${ }^{127}$ ILC Statute, supra note 119, Art. 1(1) (defining the "object" of the International Law Commission). 
forms of sources and evidence of international law, emphasizing state practice. Yet, as seen, in this case it was able to identify no state practice supporting the notion of a state's having sovereignty over the portion of transboundary groundwater in its territory. The ILC should have recognized that like the infamous and discredited Harmon Doctrine, ${ }^{128}$ these comments, by apparently but a few states, in support of the notion of sovereignty over transboundary aquifers reflect not state practice but advocacy of a position they considered supportive of their interests. Whether making such an argument concerning transboundary aquifers could ever be supportive of a state's interest is discussed below.

In addition to the lack of support in state practice for the notion of sovereignty over shared groundwater, three specific dangers relate to the use of the concept of sovereignty in this context. First, it will reinforce the historic tendency of some states to claim absolute sovereignty over the portion in their territories of even transboundary surface waters. As indicated above, such claims have long been discredited and are clearly contrary to contemporary international law. In this connection the International Court of Justice in the Gabčikovo-Nagymaros case referred to a state's "basic right to an equitable and reasonable sharing of the resources of an international watercourse." ${ }^{129}$ Indeed, the Commission's transboundary aquifers draft includes equitable and reasonable utilization as a general principle. ${ }^{130}$ The indeterminate, yet powerful, concept of "sovereignty" is anything but compatible with and supportive of the principle of "an equitable and reasonable sharing" to which states have a "basic right." "Sharing" of transboundary freshwater and "sovereignty" over it even seem mutually exclusive. Article 3's declaration that a state has sovereignty over the portion of a transboundary aquifer in its territory risks reopening what had been considered a long-dead debate between adherents of the "absolute territorial sovereignty" theory and those of the "absolute territorial integrity" theory, ${ }^{131}$ as well as encouraging states to make claims that can only generate disputes.

Second, the notion of "sovereignty" may give a state the idea that it has absolute discretion concerning the water contained in a transboundary aquifer when in fact and in law it does not. It may get this idea notwithstanding the statement in the second sentence of draft Article 3 that the state "shall exercise its sovereignty in accordance with international law and the present draft articles." The damage has already been done in the first sentence, as it clearly implies that sovereignty is the guiding principle and that the remainder of the draft must be interpreted in that light. The comments of one state evidence acceptance of this implication by supporting the notion of sovereignty of aquifer states because it "emphasiz[es] that sovereignty is the fundamental rule on which the entirety of the draft articles is based so that the latter have to be interpreted accordingly." 132 Thus, the first sentence of Article 3 lets the genie of sovereignty out of the bottle, and the second sentence cannot put it back in. The state is clearly sovereign over the water-bearing geologic formation itself, up to the point where the border intersects it. ${ }^{133}$ It has rights of use in, but not sovereignty over, the water contained in that formation.

\footnotetext{
128 See note 117 supra.

129 Gabčíkovo-Nagymaros Project, supra note 113, 1997 ICJ REP. at 54, para. 78.

${ }^{130}$ Article 4, Equitable and Reasonable Utilization, 2008 ILC Report, supra note 1, at 21.

${ }^{131}$ For a discussion of these theories in state practice and the views of publicists concerning them, see MCCAFFREY, supra note 27, at 112-26, and 126-35, respectively. See also text at note 135 infra.

${ }^{132}$ Comments and Observations by Governments, supra note 99, comment of Austria, at 21-22.

133 This point may not always be simple to determine, just as the precise location of surface boundaries is not always obvious.
} 
At most, therefore, the state could be said to have "sovereign rights" in the water contained in the aquifer, though how that would differ from the state's having mere "rights" in that water is not at all clear.

Third, the notion that states are sovereign over the portions of shared freshwater resources located in their respective territories raises the classic problem of how the sovereignties of the two (or more) states sharing surface water or groundwater are to be reconciled: under this provision, all states sharing a given groundwater resource are sovereign over the portion of it located in their respective territories. If we then posit that the water in a transboundary aquifer flows from state $A$ to state $B, A$ may claim that its freedom to dispose of the water while it is in its territory enables it to use the groundwater virtually ${ }^{134}$ as it wishes because of its sovereignty over that water; but state $B$, which may have begun using the shared groundwater before state $A$, could equally claim that $B$ 's sovereign right to receive the water contained in the aquifer over which it-state $B$ - has sovereignty is being violated by $A$ through $A$ 's use of the shared resource. These claims would be supported, respectively, by the "absolute territorial sovereignty" and the "absolute territorial integrity" theories, ${ }^{135}$ which have now been overtaken by the development of the customary international law of international watercourses as reflected in the UN Convention. It is the irreconcilability of these theories, caused by their basis in sovereignty, that led to the development of the doctrine of equitable utilization, as enunciated by the ICJ in the Gabčikovo-Nagymaros case. ${ }^{136}$ The sharing of freshwater in an equitable and reasonable way will not be promoted by starting from a position of sovereignty over it.

\section{CONCLUSION}

The ILC's draft articles on the law of transboundary aquifers can potentially make an important contribution to the codification and progressive development of the law and offer useful assistance to states sharing groundwater. They reflect a sophisticated understanding of the nature of groundwater and aquifers, which is all too rare in the law, whether domestic or international. But rather than picking up where the 1997 UN Convention left off, the Commission's draft purports to regulate not only shared freshwater that the UN Convention does not cover, but also that which it does cover. This overlap will inevitably sow the seeds of confusion and potential conflicts. The draft also introduces a wild card into the field in the form of its general principle of "sovereignty of aquifer states." These considerations counsel caution on the part of the UN General Assembly in determining the fate of the draft articles. The ILC itself has proposed that the Assembly adopt a cautious approach by recommending that it "take note" of the articles at present and consider only at "a later stage" whether they should serve

\footnotetext{
${ }^{134}$ State $A$ 's freedom to dispose of the shared water would not be complete because of the obligations of equitable and reasonable utilization (Art. 4) and prevention of significant harm (Art. 6). But those provisions would operate only as limitations on the "sovereignty" conferred by Article 3 and in many cases would be more likely to be raised by the affected state (here, state $B$ ) after the activity producing the effects had begun rather than by the acting state (here, state $A$ ).

135 See MCCAFFrEY, supra note 27 , at 112-35.

${ }^{136}$ See id. at 384; see also text at note 129 supra (quoting Gabčíkovo-Nagymaros Project, supra note 113, 1997 ICJ REP. at 54).
} 
as the basis for negotiating a convention. ${ }^{137}$ The Assembly followed this recommendation in a resolution adopted in December 2008. ${ }^{138}$ If the General Assembly ultimately does decide to convene a conference to negotiate such a convention, the integrity of the legal regime thus established will crucially depend on eliminating both the overlap between the draft and the UN Convention in terms of the physical subject matter they regulate, and the notion of "sovereignty" over shared groundwater, which should have no place in any set of rules governing the use, protection, and management of shared freshwater resources.

${ }^{137} 2008$ ILC Report, supra note 1 , at 18.

138 The Law of Transboundary Aquifers, GA Res. 63/124, para. 6 (Dec. 11, 2008) (deciding to include this item in the provisional agenda of the Assembly's sixty-sixth session-i.e., three years hence- "with a view to examining, inter alia, the question of the form that might be given to the draft articles"). 